\title{
De los "gentries" a los precarios urbanos. Los nuevos residentes del centro del Santiago
}

Yasna Contreras. Universidad de Chile, Santiago, Chile.

RESUMEN | Las transformaciones socioespaciales de la comuna de Santiago llevan a plantear la tesis de que ellas son concomitantes al arribo de habitantes de diferentes orígenes residenciales, situación que se manifiesta en la coexistencia de procesos de gentrificación, verticalización y tugurización. El propósito del estudio fue indagar esta realidad desde una dimensión cualitativa y aleatoria, para lo cual se aplicaron 64 entrevistas en profundidad en las cuatro zonas de mayor cambio en la comuna. Su objetivo fue definir tipos urbanos ideales en la población actual del centro de la ciudad, de los cuales se identificaron cinco categorías: gentrie pionero, gentrie sucesor, transitorio urbano, decadente y precario. Cada una de estas categorías representa una construcción mental que permite comprender los fenómenos de cambio socioespacial que afectan las áreas centrales. La tipología así definida resultó del cruce de variables claves, como la trayectoria residencial y socioprofesional, el nivel de ocupación, tipos de inmuebles habitados, y el sentido de sus prácticas espaciales. Sus divergencias y convergencias apelan al diseño de nuevas políticas urbanas y de vivienda para espacios centrales.

PALABRAS ClaVES | movilidad, gentrificación y centros urbanos.

ABSTRACT | The socio-spatial transformations that have taken place in the municipality of Santiago support the thesis that they relate to the arrival of inhabitants of diverse residential origins, situation that is manifested in the coexistence of gentrification verticalization and slumming processes. The purpose of the research was to understand this reality from a qualitative and random dimension; therefore 64 in-depth interviews -in four areas of major change of the commune-were conducted. The objective was to define ideal urban types among the actual population of the city center, from which five categories were identified: gentrie pioneer, gentrie successor, urban transient, decadent and poor. Each of these categories represents a mental construct that allows comprehending socio-spatial phenomenon of change that affects the central areas. The typology as defined, resulted as an intersection of key variables, such as the residential and socio-professional trajectory, the occupation level, types of inhabited spaces, and the purpose of their spatial practices. Their divergences and convergences appeal to the design of new urban and housing policies for central spaces.

KEYWORDs | Mobility, gentrification, urban centres. 


\section{Introducción}

El punto de partida de este artículo es la constatación de que algunos barrios de la comuna de Santiago acogen a habitantes de diferentes ingresos y orígenes residenciales, lo que lleva a plantear la tesis de un centro mosaico socioespacial donde conviven hogares de diferentes ingresos, estilos de vida y trayectorias socioresidenciales y profesionales. Como área central se comprenden aquellos barrios de la comuna de Santiago en la ciudad homónima que consolidan una nueva forma urbana, expresiva de diferentes formas de ocupación del espacio: de una parte, densificación y verticalización; de la otra, tugurización y hacinamiento, consustancial a la forma desigual de producción de capital (Harvey, 2007).

Al menos desde hace veinte ańos, tras el retorno a la democracia a inicios de los años noventa, la comuna de Santiago se ha estado configurando como un espacio de coexistencia de diferentes grupos socioeconómicos y agrupaciones inmobiliarias. Tal coexistencia tiene sus orígenes en un proceso de empresarialismo urbano (Harvey, 2007), resultante de un Plan de Repoblamiento que generó un modo de gobernanza -casi exclusivo de Chile- donde se involucraron agentes públicos y privados en complejas relaciones de poder (Barton, 2008), a objeto de rentabilizar espacios del centro de la ciudad deteriorados tras el terremoto de 1985. El Plan de Repoblamiento emergió como estrategia del gobierno local y como respuesta a los diagnósticos realizados por la Corporación de Desarrollo de Santiago (Cordesan), ${ }^{1}$ creada en 1985 en el marco del terremoto. Aludir al Plan de Repoblamiento como mecanismo representativo del empresarialismo urbano es una respuesta a todas las estrategias que se diseńaron para volver el centro de la ciudad un espacio atractivo para la inversión y captura de rentas diferenciadas (Smith, 1979).

Para convertir la comuna de Santiago en un espacio residencial atractivo para clases medias y medias altas, a través del Plan de Repoblamiento se diseñaron condiciones favorables a la valorización privada del capital inmobiliario. En esta línea puede situarse la acción de la Cordesan, en tanto respuesta a la necesidad de generar demandas y ofertas residenciales al interior de la comuna, en un escenario caracterizado en ese momento por el deterioro y abandono. Conjuntamente, el gobierno central aprobó en 1987 la Ley de Renovación Urbana, que regularía diferentes municipios con espacios deteriorados pero bien conectados. A ello se sumaría en 1991 la aprobación de un Subsidio de Renovación Urbana que facilitó iniciativas inmobiliarias al interior de la comuna de Santiago, al generar un voucher de casi US\$ 7.800. Este instrumento estaba orientado a facilitar el acceso formal a la vivienda en altura, pero privilegiando sobre todo a los agentes inmobiliarios, quienes capturarían el subsidio como mecanismo de atracción de nuevas demandas residenciales (Contreras, 2011). Asimismo, se configuró una bolsa de demanda como mecanismo de absorción de demanda endógena, especialmente de residentes

1 La Cordesan es una institución privada que nació en 1985 sin fines de lucro. Tiene como principal representante al alcalde o gobernador local. En sus orígenes estuvo orientada a generar una demanda y oferta de viviendas para hogares residentes de la comuna de Santiago. No obstante, con el tiempo y al articularse con inversionistas inmobiliarios, se configuró como una empresa de gestión inmobiliaria. 
afectados por el terremoto. Sumado a lo anterior, el gobierno local implementó estrategias de marketing urbano que jugaban con el imaginario de un área central repoblada, tranquila y verde.

Todas estas acciones constituyeron una estrategia innovadora del ámbito público y privado. Como resultado, el sector inmobiliario y comercial saturó diferentes sectores de la comuna de Santiago, permeando su presencia hacia los municipios pericentrales, cuyas normativas urbanas son flexibles y permisivas para la acción inmobiliaria (López Arriagada, Gasic \& Meza, 2015). Los datos del Observatorio Habitacional del Ministerio de Vivienda y Urbanismo (Minvu, 2016) muestran que entre los ańos 2002 y 2014, en las comunas pericentrales de Santiago se construyeron casi 250.000 departamentos (36,5\% de la oferta de la ciudad de Santiago), en tanto el municipio de Santiago concentró casi el 50\% del total de departamentos edificados, lo que lleva a plantear la tesis de la consolidación de la comuna central como espacio de la verticalización.

La gestión pública de la Cordesan y del Municipio de Santiago estuvo orientada a entregar garantías al desarrollador inmobiliario; en específico, arreglos normativos, aumentos en las rasantes y coeficientes de constructibilidad, valores de suelos bajos en sitios en estado de demolición o baldíos. Desde esa fecha, la gestión urbana de la Cordesan se configura como un nexo entre el gobierno local y las diferentes inmobiliarias y constructoras interesadas en invertir en la comuna. El Plan fue diseñado como una estrategia de empresarialismo urbano, en tanto la Cordesan facilitó todas las acciones y lotes en desuso para la construcción de edificios en altura; a su amparo se especuló con el valor del suelo, se facilitó la normativa urbana y se establecieron alianzas públicas-privadas (Contreras, 2011).

En el marco de lo expuesto, el artículo tiene como propósito identificar qué hogares e individuos llegaron a la comuna de Santiago desde 1990, especialmente en las zonas de mayor construcción en altura, en sitios de reciclaje de antiguos inmuebles y en los espacios de tugurización y hacinamiento. La investigación se concentró en las cuatro áreas de mayor cambio pos Plan de Repoblamiento. Metodológicamente, se aplicaron 64 entrevistas en profundidad (figura 1), lo que permitió identificar cinco tipos ideales de residentes: gentries pioneros (7); gentries sucesores (9); transitorios urbanos (31); decadentes urbanos (6) y, finalmente, precarios urbanos (15), que incluyen nativos e inmigrantes latinoamericanos. Las áreas analizadas y expuestas en la figura 1 coinciden, a su vez, con diferentes barrios, a saber: zona 1 , compuesta por los barrios Lastarria-Bellas Artes; zona 2, representada por el Centro Histórico tradicional de la ciudad; zona 3, comprendida por los barrios Brasil y Yungay; y finalmente la zona 4, los barrios Lira y Almagro, sectores que representan la última fase del Plan de Repoblamiento, en tanto desde el año 2010 se congelaron los permisos de edificación.

A partir de la identificación de tipos ideales, se pretende determinar cómo la comuna de Santiago es representativa de un paisaje urbano y social que evidencia no solo diferentes sujetos sociales, sino también las tensiones producidas entre un mercado inmobiliario que rentabiliza el deterioro, y otro informal que se beneficia de una demanda residencial de sujetos vulnerables y precarios que requieren de espacios bien conectados a sus redes laborales, sociales y familiares. El acceso 
informal a la vivienda es el resultado de la incapacidad del sistema de producir vivienda para hogares de bajos ingresos en espacios centrales. Esto último, agudizado por un sistema que produce una "casa propia" que no resuelve el problema de los sin techo. Por otra parte, la coexistencia de un mercado formal de acceso a la vivienda y de uno informal, también es resultado de la lógica de producción capitalista manifiesta en una desigual distribución del poder y de la renta (Harvey, 2003, 2007) y en procesos de inversión que se superponen a otros de desinversión, generando con ello nuevas fronteras urbanas (Smith, 1996) que hacen de las áreas centrales espacios complejos de analizar.

\section{FIgURA I | Comuna de Santiago y barrios de estudio}

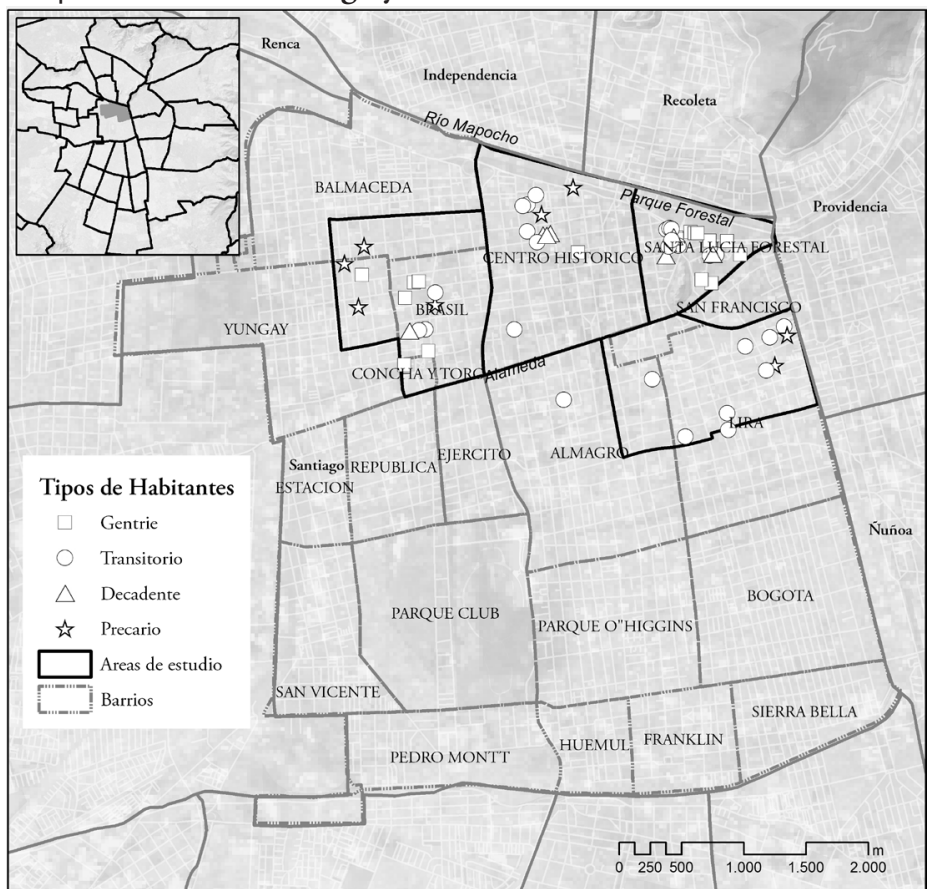

FUENTE ELABORACIÓN PROPIA, A PARTIR DE DATOS DEL OBSERVATORIO HABITACIONAL MINVU (MINVU, 20I6)

\section{Marco conceptual}

Con el objetivo de hacer un mapa de los sujetos sociales que identifican los diferentes estudios sobre la gentrificación y tugurización, en este apartado se busca precisar aquellos elementos que permitan construir tipos ideales dentro de la comuna de Santiago, las diferencias entre ellos, en un enfoque contestatario a la simple tesis de la gentrificación como fenómeno exclusivo tras los cambios en espacios centrales. Más bien, se intenta demostrar que en un contexto de empresarialismo urbano, los procesos sociales coexisten y exigen una nueva reinterpretación de los sujetos generadores del cambio. 
Las áreas centrales como espacios de coexistencias entre diferentes grupos sociales Desde mediados de los ańos setenta emergen de la literatura diversos tipos de habitantes urbanos, una realidad para la cual se acuñan diversos conceptos, como gentries (Glass, 1964; Ley, 1980; Smith 1982, 1996), analistas simbólicos (Reich, 1993), nuevos bohemios (Lloyd, 2002), entre otros. El abanico de estos nuevos habitantes se inscribe en un tipo o modo de vida ideal reconocido por la literatura como citadino, fuertemente definido por el contexto económico, social y cultural en que habitan, y por las diferentes razones que los llevan a preferir determinados barrios del centro. Ellos son reflejo de los cambios sociales, económicos y urbanos de las ciudades en el marco de cuestionados procesos de renovación urbana, pero también son tipos difícilmente exportables a las realidades latinoamericanas.

Los términos enunciados refieren a nuevos grupos sociales que invaden espacios centrales en el marco de procesos de recuperación urbana y gentrificación. Por su parte, hogares de bajos ingresos ven los barrios centrales como sitios residenciales y espacios ancla para la promoción social, residencial y espacial (Contreras, 2012; Dureau \& Bonvalet, 2002). Por tanto, asumir que solo gentries y grupos de mayor condición socioeconómica son los que generan las mutaciones de áreas centrales resultaría limitado, en tanto lo informal y lo formal en el acceso a la vivienda coexisten geográficamente (Smolka \& Biderman, 2011). También en las áreas centrales de las ciudades se alojan sujetos que están limitados a habitar en inmuebles tugurizados, en tanto existen barreras institucionales que dificultan la provisión de viviendas de interés social para hogares de bajos ingresos en barrios centrales (Abramo, 2012; Jaramillo, 2008).

La coexistencia de diferentes grupos en las áreas centrales refleja las transiciones y transformaciones que se dan en dichos espacios, cambios que se hacen manifiestos en la superposición -simultánea o secuencial- de procesos de renovación, inversión y gentrificación, con otros de tugurización, desinversión y deterioro. Tal coexistencia espacial de hogares de ingresos bajos como otros grupos medios o medios alto no implica, sin embargo, necesariamente integración social, por cuanto los vínculos sociales entre ellos no se hacen evidentes o no parecen darse (Rasse, 2015).

En esta discusión sobre los distintos grupos sociales habitantes de áreas centrales se intenta explicitar qué hace diferentes a los nuevos residentes de esos barrios respecto de otros grupos similares que arribaron en épocas anteriores. Para ello se recurre a sus trayectorias residenciales y familiares, estrategias residenciales, prácticas espaciales y sus formas de movilidad social como factores explicativos del sentido que asignan a las áreas centrales. Se establece un comportamiento diferenciado en función de variables como género, edad, educación, empleo, representaciones, proyectos de vida e importancia asignada a los lugares (Scheiner \& Kasper 2002). Lo interesante es descubrir si las elecciones residenciales centrales y las prácticas espaciales de estos nuevos habitantes tienen el mismo significado que las de los antiguos, y si es posible calzarlos dentro de un modo de vida particular.

La literatura internacional se refiere a la llegada de clases medias acomodadas y profesionales a las áreas centrales. Sin embargo, gran parte de estas nuevas categorías están vinculadas a la tesis de la gentrificación como manifestación de un cambio de la sociedad no solo desde una dimensión simbólica, sino también en términos de 
los espacios que se escogen. La socióloga británica Ruth Glass (1964) fue una de las pioneras en identificar nuevos grupos sociales que penetraban a las áreas urbanas deterioradas de Londres a mediados de la década de los sesenta. Denominó gentrie a este grupo, gente de suburbia -los suburbios y la forma de vida y actitudes, entre otros aspectos, de quienes viven allí- que hoy valorizan una vida urbana central. Más tarde, Appleyard (1979) sostenía que el repoblamiento en áreas deterioradas y en proceso de renovación urbana resultaba de la presencia de dos actores secuenciales: los "pioneros" (pioneers) seguidos por los gentries. Los primeros comprendían artistas, diseñadores o estudiantes que invadían barrios ocupados por población de bajos ingresos, y que se distinguían de los gentries porque no pertenecían a la burguesía o renegaban de ella, valorando la mezcla social. Los gentries, en tanto, corresponden a las clases altas que retornan a los barrios deteriorados, invadiendo y desplazando a hogares de bajos ingresos, aunque en Latinoamericana no necesariamente el gentrie regresó desde los espacios de suburbia (Contreras, 2011; Herzer, 2008). El desplazamiento, por ende, se convierte en una de las principales externalidades de un proceso de gentrificación, independientemente de la escala del fenómeno.

Parte de la literatura pos-Glass apela a la llegada de clases medias profesionales y técnicas para acotar el proceso de gentrificación, e incluso se alude a nuevas clases medias. Cabría por tanto cuestionarse qué es lo nuevo de estas clases respecto a clases medias similares de otras épocas. Smith (1996) sostiene que la clase media no se distingue de otros grupos según sus ingresos, sino más bien en función de un criterio laboral, político, educacional y quizás cultural. Presumiblemente, el trabajo administrativo y profesional crea una autoconcepción del propio rol social que opera como marca diferenciadora respecto de otros segmentos sociales, lo que puede traducirse en opciones de consumo igualmente diferentes, que resultan en concentración espacial en el centro de la ciudad. Anclarse solo en el criterio laboral y económico para caracterizar al nuevo residente resulta limitado, por cuanto otras variables permitirían diferenciar a un grupo social respecto de otros.

Teóricamente, la emergencia de nuevos habitantes en áreas centrales se asocia a los procesos de reestructuración económica, marcados por el tránsito desde una ciudad industrial-fordista a una posindustrial sustentada en la economía de servicios desde la década de los setenta en adelante (Ley, 1980). Poco se ahonda en los cambios sociodemográficos, culturales y los recorridos residenciales y familiares como explicativos de nuevas elecciones por la centralidad. Diferentes autores (Hamnett 1991, 2003; Ley, 1980, 1986) escriben sobre el surgimiento de una nueva clase social de súper profesionales que están conectados a escala mundial y se identifican a escala local, que optan por las áreas centrales de las ciudades imprimiéndole sus propias formas al espacio, transformándolo y entrando en disputa con otros de más bajos ingresos (Butler, 2007). Algunos de ellos son personajes sensibles al paisaje urbano y al carácter social que adoptan los barrios elegidos, otros posiblemente sean habitantes pasajeros para quienes los barrios centrales representan, objetiva o subjetivamente, una etapa del ciclo de vida.

Authier (2001), analizando diferentes barrios centrales, identifica tres tipos de habitantes que responden a una primera fase de gentrificación: ascendentes culturales, ascendentes técnicos y nuevos arrendatarios (cuadro 1). 
CUADRo I | Nuevos tipos de habitantes a partir de sus trayectorias residenciales y prácticas espaciales

\begin{tabular}{|c|c|c|c|}
\hline $\begin{array}{c}\text { TIPO DE } \\
\text { HABITANTE }\end{array}$ & RASGO DOMINANTE & $\begin{array}{l}\text { PRÁCTICAS DE MOVILIDAD } \\
\text { RESIDENCIAL }\end{array}$ & ANCLAJE \\
\hline \multirow{3}{*}{$\begin{array}{l}\text { Ascendentes } \\
\text { culturales }\end{array}$} & Jóvenes parejas activas & $\begin{array}{l}\text { Arriban en un período de fuerte } \\
\text { movilidad residencial }\end{array}$ & \multirow{3}{*}{$\begin{array}{l}\text { Búsqueda de la histo- } \\
\text { ria y la convivencia er } \\
\text { un barrio }\end{array}$} \\
\hline & Clases medias asalariadas & Acceden a la copropiedad & \\
\hline & Elevado capital cultural & Libertad de elección residencial & \\
\hline \multirow{3}{*}{$\begin{array}{l}\text { Ascendentes } \\
\text { técnicos }\end{array}$} & Hogares menos jóvenes & \multirow{3}{*}{$\begin{array}{l}\text { Pueden ser habitantes de } \\
\text { retorno }\end{array}$} & \multirow{3}{*}{$\begin{array}{l}\text { Menor deseo de apro- } \\
\text { piación simbólica- } \\
\text { cultural del barrio }\end{array}$} \\
\hline & $\begin{array}{l}\text { Franjas superiores de la } \\
\text { clase obrera que acceden a la } \\
\text { copropiedad }\end{array}$ & & \\
\hline & $\begin{array}{l}\text { Dotados de capital técnico } \\
\text { elevado }\end{array}$ & & \\
\hline \multirow{4}{*}{$\begin{array}{l}\text { Nuevos } \\
\text { arrendatarios }\end{array}$} & Grupo más vulnerable (frágil) & \multirow{4}{*}{$\begin{array}{l}\text { Cambio residencial más } \\
\text { limitado }\end{array}$} & \multirow{4}{*}{$\begin{array}{l}\text { Llegada al barrio se } \\
\text { inscribe en una lógica } \\
\text { funcional }\end{array}$} \\
\hline & $\begin{array}{l}\text { Jóvenes, especialmente } \\
\text { solteros }\end{array}$ & & \\
\hline & $\begin{array}{l}\text { Ejercen una actividad profe- } \\
\text { sional precaria }\end{array}$ & & \\
\hline & $\begin{array}{l}\text { A veces combinan actividades } \\
\text { laborales "paralelas" (en el } \\
\text { campo cultural o artístico) }\end{array}$ & & \\
\hline
\end{tabular}

FUENTE ELABORACIÓN PROPIA A PARTIR DE AUTHIER (2OOI)

La tipología de Authier (2001) sintetizada en el cuadro 1 devela la presencia de "diferentes categorías sociales que permiten observar formas marcadas de la división social del espacio" (p. 115), y que no pueden resumirse en la llegada de nuevas clases medias a barrios centrales, como lo plantean las diferentes corrientes teóricas sobre gentrificación (Ley, 1980, 1986; Hamnett, 1991, 2003). Los tipos propuestos por Authier no se configuran como categorías homologables a todas las áreas centrales, sino más bien son una primera aproximación respecto a qué vuelve comunes o diferentes a los habitantes de los espacios centrales franceses según sus características sociodemográficas y las trayectorias residenciales. Por tanto, cualquier propuesta de nuevos habitantes debe al menos considerar variables tales como "modelos culturales, los efectos de moda, los cambios en el curso de las sociedades" (Bonvalet \& Dureau 2002, p. 72), entre otros.

En el caso latinoamericano, antes de la década de los sesenta, coexistían en los espacios centrales usos residenciales, industriales y comerciales, al igual que diferentes grupos sociales (Carrión, 2001, 2005; Contreras, 2011, 2012; Hidalgo, Salazar \& Álvarez, 2003; Rojas, 2005). No se desconoce la mixidad socioespacial que caracteriza los espacios centrales, más bien, es necesario preguntarse qué es lo diferente de estas dos últimas décadas. Como hipótesis se sostiene que los cambios socioculturales y la masividad de una oferta inmobiliaria variada cautivaron a hogares de diferentes orígenes residenciales y movilidades socioprofesionales. Estos 
habitantes tienen prácticas espaciales y trayectorias residenciales, e incluso enraizamientos distintos a las viejas clases medias que habitan los barrios de la comuna de Santiago. Asimismo, la generación pionera de las transformaciones socioespaciales de esta comuna, al menos en las dos últimas décadas, acoge a jóvenes profesionales y/o técnico que buscan reconstruir para sí una identidad urbana diferenciadora. No obstante, nuevas investigaciones debiesen cuestionarse qué elementos marcan las divergencias entre ellos, ¿la búsqueda de prestigio, de estatus, de reafirmar una cultura urbana? Los perseguidores de lo cool constituyen la última ola migratoria al barrio, y están conformados por arrendatarios pertenecientes a clases medias, jóvenes con alta heterogeneidad cultural e identitaria que se apropian del barrio a partir de su prestigio y arquitectura.

La literatura latinoamericana ha hecho extensible las categorías angloamericanas a la hora de caracterizar a los individuos y familias que llegan a barrios centrales, aquí se debe volver a la raíz latinoamericana en términos de las formas de producir vivienda y los arraigos / desarraigos que imprimen sus habitantes. Uno de los principales aportes proviene de los trabajos organizados por Herzer et al. (2008) sobre los cambios sociourbanos de los barrios localizados al sur de la ciudad de Buenos Aires, donde se reconoce que quienes arriban están representados por clases medias que consumen símbolos de estatus, tales como departamentos bellos y viejos edificios, para expresar su distancia social de las clases inferiores.

\section{Metodología}

Como espacio de análisis se estudia la comuna de Santiago, territorio homónimo de la ciudad capital de Chile (figura 1). De casi 215.000 habitantes al año 2002 (Instituto Nacional de Estadísticas, Censo 2002), pasó a configurarse como la comuna con más habitantes a nivel nacional según el Censo 2012, alcanzando casi los 309.000 habitantes (1,9\% del total país). Tiene una superficie de $22,4 \mathrm{~km}^{2}$, que alberga las principales instituciones públicas de carácter nacional. En su interior están delimitados 19 barrios, de los cuales siete son objeto de esta investigación, agrupados en cuatro zonas de estudios donde coexisten la construcción de edificios en altura (verticalización), el reciclaje de antiguos inmuebles, la tugurización, así como la recuperación de espacios públicos. El criterio de definición apunta a espacios de inversión y desinversión bajo una lógica empresarialista del gobierno local y central, la cual es consustancial a un capital inmobiliario para el que resulta rentable invertir en espacios e inmuebles deteriorados.

La zona 1 está representada por el centro histórico tradicional de la ciudad, donde se concentra parte de los inmuebles históricos y que hoy se ve sometida a una intensiva construcción de edificios en altura, especialmente en su borde poniente, próximo a la Autopista Central. La zona 2 está integrada por los barrios Bellas Artes y Lastarria, los que siempre han atraído a una élite artística y cultural. La zona 3 incluye los barrios obreros y grupos de ingresos medios y medios bajos que habitan los barrios Concha y Toro y Yungay. Finalmente, la zona 4 concentra los barrios Lira y Almagro, sitios que acogieron la última etapa de la renovación en altura en el marco del Plan de Repoblamiento, dada la disponibilidad de sitios y espacios en 
desuso, así como antiguas viviendas y posibles de regenerar y verticalizar. A su vez, la existencia de viviendas antiguas en pasajes y cités en esta cuarta zona actúa como atracción para inmigrantes de bajos ingresos que acceden a un mercado de vivienda informal (Contreras, Ala-Louko \& Labbé, 2015).

Con una modalidad aleatoria, se aplicaron 64 entrevistas en profundidad en las cuatro zonas de estudios en diferentes momentos, entre los años 2009 y 2011. La realización de entrevistas correspondió a una metodología cualitativa no basada en la representatividad de todos los habitantes llegados a la comuna de Santiago desde 1990 en el marco del Plan de Repoblamiento; se buscó, más bien, una muestra aleatoria que se aproximara lo mejor posible a los tipos de habitantes que residen en zonas de coexistencia entre la renovación, gentrificación y tugurización. Esto último, porque gran parte de las variaciones socioculturales de los nuevos residentes no aparecen en los registros censales chilenos. Interesó conocer quiénes son estos habitantes, qué diferencias existen entre aquellos que optaron por la densificación versus los que prefieren el reciclaje de antiguas construcciones como formas y modos de vida. Se llegó de esta forma a cinco tipos de habitantes, como aproximaciones empíricas a la diversidad de sujetos que viven en la comuna de Santiago, y con el sesgo sociológico de asumir que "un tipo ideal es un concepto o representación mental (situado en la mente del historiador, del sociólogo o del teórico económico)" (De Donato, 2007, p. 155). Los tipos de habitantes aquí sugeridos devienen en constructos conceptuales que reflejan una ideología neoliberal en un espacio y tiempo determinados.

Tal como se resume en el cuadro 2, se indagaron, en primer lugar, cinco variables: estado civil, estructura familiar, categorías socioocupacionales, ingreso per cápita, tipo de alojamiento y tenencia de la vivienda. Conjuntamente, se estudiaron las trayectorias residenciales de los entrevistados, con el propósito de comprender el sentido de sus cambios residenciales, así como también sus condiciones de habitabilidad. Los entrevistados nacieron y vivieron mayoritariamente en la ciudad de Santiago, pero también en otras ciudades del país o en otros países (Perú, Colombia, Ecuador y Venezuela) antes de su estadía en el centro de la ciudad. Se construyó el universo entrevistado según muestreo "bola de nieve" a partir de informantes claves que conocieran los aspectos centrales del contexto social y la vida cotidiana de los barrios estudiados. Entre estos destacan: presidentes de Juntas de Vecinos, entre ellas las de los barrios Forestal, Yungay, Matta, Lastarria, Brasil; ejecutivos inmobiliarios que entregaron información sobre sus compradores (residentes o inversionistas); contactos entregados por la Municipalidad de Santiago y por propietarios o arrendatarios de locales comerciales. Se entrevistó a 32 hombres y 32 mujeres en las cuatro zonas que componen la investigación. El perfil de los entrevistados se resume en el cuadro 2, considerando variables como edad, estructura familiar, categorías socioocupacionales, ingreso per cápita, tipo de alojamiento y tenencia de la vivienda. De estas categorías, la única variable que no se configuró como significativa para diferenciar un sujeto de otro fue Ingreso per cápita. En todos los casos, se interrogó a un único individuo por hogar, el jefe o jefa de hogar o cónyuge. Salvo algunas entrevistas, se logró conversar con el resto del grupo familiar. Las entrevistas fueron realizadas entre marzo de 2009 y agosto de 2011. 
CUAdro 2 | Perfil de los entrevistados en las cuatro zonas de estudio de la comuna de Santiago

\begin{tabular}{|c|c|c|c|}
\hline \multicolumn{2}{|l|}{ ESTADO CIVIL } & ESTRUCTURA FAMILIAR & $\mathbf{N}^{\circ}$ TOTAL \\
\hline Casado (a) & 12 & Pareja sin hijos & 13 \\
\hline Conviviente & 11 & Soltera con 1 hijo & 1 \\
\hline Separado (a) & 8 & Vive con familia & 1 \\
\hline Soltero (a) & 31 & Vive solo & 33 \\
\hline Viudo (a) & 2 & Pareja con hijo (1 o 2) & 12 \\
\hline Total & 64 & Separada con hijos & 4 \\
\hline \multicolumn{2}{|l|}{ CATEGORÍAS SOCIOOCUPACIONALES } & \multicolumn{2}{|c|}{ INGRESO PER CÁPITA (SEGÚN CATEGORÍA GSO) } \\
\hline Artista & 6 & Artistas & 1.145 .000 \\
\hline Dueńa de casa & 2 & Dueña de casa & 725.000 \\
\hline Empresario & 5 & Empresario & 2.400 .000 \\
\hline Jubilada & 4 & Jubilada & 126.250 \\
\hline Profesional científico e intelectual & 4 & Profesional científico e intelectual & 1.937 .500 \\
\hline Profesionales a nivel medio & 29 & Profesionales a nivel medio & 1.002 .299 \\
\hline Trabajador a honorario privado & 1 & Profesionales a nivel medio-técnico & 747.500 \\
\hline Trabajador independiente & 7 & Trabajador a honorario privado & 400.000 \\
\hline Profesionales a nivel medio-técnico & 6 & Trabajador independiente & 251.667 \\
\hline Total & \multicolumn{3}{|l|}{64} \\
\hline \multicolumn{2}{|l|}{ TIPO DE ALOJAMIENTO } & \multicolumn{2}{|c|}{ TENENCIA DE LA VIVIENDA } \\
\hline Casa antigua & 11 & Arrendatario & 23 \\
\hline Departamento antiguo & 1 & Propietario & 41 \\
\hline Departamento antiguo no rehabilitado & 5 & Total & 64 \\
\hline Departamento antiguo rehabilitado & 16 & SEXO & $\mathrm{N}^{\circ}$ TOTAL \\
\hline Departamento nuevo & 27 & Hombre & 32 \\
\hline Departamento nuevo - loft & 4 & Mujer & 32 \\
\hline Total & 64 & Total entrevistados & 64 \\
\hline
\end{tabular}

FUENTE CONTRERAS (2OI2)

Las edades de los entrevistados fluctuaron entre los 25 y 70 años (cuadro 2), aunque la mayoría tenía en promedio 40 años. Los adultos mayores entrevistados habitaban mayoritariamente en los barrios Bellas Artes y Lastarria. Los más jóvenes residen en los barrios Brasil y Santa Isabel. Del conjunto, 31 son solteros, 12 casados, 11 convivientes, 8 separados y 2 viudas. Se trata principalmente de personas solas (33 entrevistados); 13 responden a parejas sin hijos, 13 son parejas con 1 o 2 hijos. En un gran número de casos son propietarios de sus departamentos (41 de ellos); otros entrevistados accedieron a departamentos nuevos (27 casos); otros a departamentos antiguos (16 casos); otros a edificios asimilados a lofts (4 casos); otros reciclaron antiguos inmuebles (11 casos) y el resto habita en viviendas y piezas subarrendadas (10 casos). Los inmigrantes provienen de Perú, Ecuador, Venezuela y Colombia y 
se localizan preferentemente en torno a la calle Santa Isabel o sus alrededores, y en los barrios Brasil y Yungay.

Las categorías socioocupacionales son coincidentes con los datos derivados del último Censo de Población y Vivienda para el período intercensal 1992-2002. Representan a profesores, técnicos de empresas privadas y de servicios, sociólogos, arquitectos, ingenieros, geógrafos, psicólogos, entre otros afines. Destacan siete trabajadores independientes, que corresponden principalmente a migrantes latinoamericanos; algunos son arrendatarios de almacenes de barrios, otros contratistas y otros cuidadores de auto. Se suman otras seis personas que son trabajadores privados a honorarios, en empresas de servicios y comercio. Dentro de la muestra, y en especial en los barrios Bellas Artes y Lastarria, existen "artistas" ligados al diseño, a librerías, entre otras actividades afines. Hay cuatro casos de profesionales científicos e intelectuales que trabajan en algunas universidades públicas del país. Finalmente, se registraron cuatro casos de personas inactivas, que corresponden a mujeres jubiladas.

\section{Resultados}

Lo particular del cambio socioespacial en la comuna de Santiago es la persistencia de múltiples fenómenos que tienen lógicas y formas de representación diferenciadas, actores diferentes, espacios y tiempos convergentes. Lo diferente no es la presencia de fenómenos antagónicos (tugurización vs. renovación), sino más bien las mutaciones que dichos procesos conllevan en el espacio urbano y el rol que en ellos se le asigna al centro como una opción residencial, sea para habitantes de mayores ingresos, sea para móviles de menores ingresos (mayoritariamente migrantes latinoamericanos), que valoran la centralidad y que imprimen una condición de mezcla socioespacial esa zona de la ciudad (Contreras, 2012). La mezcla social -o mixité sociale, en el ámbito francés- refiere a la "mezcla de diferentes categorías sociales" (Baudin, 2000, p. 3), o bien a la presencia simultánea o la cohabitación en un mismo lugar de persona o grupos diferentes socialmente, con características culturales, edades, orígenes y nacionalidades disímiles.

Más que un estado y en una mirada de largo plazo, la mezcla socioespacial puede comprenderse como un medio para llegar a establecer políticas urbanas y habitacionales que promuevan un acceso igualitario a la ciudad. Sin embargo, tal enfoque se ve escasamente reflejado en las formas de empresarialismo urbano con que se ha configurado el centro de Santiago al menos en las dos últimas décadas.

\section{De los gentries a los precarios urbanos:}

\section{¿estimulando procesos de mezcla socioespacial?}

El arco que va de los gentries a los precarios urbanos comprende cinco categorías: gentrie pionero, gentrie sucesor, residente transitorio, decadente, precario (cuadro 3). Ellas resultaron de la aplicación de entrevistas en profundidad en diferentes sectores de la comuna de Santiago, especialmente en aquellos donde se identificaron procesos de gentrificación e inversión, simultáneos a otros de deterioro, tugurización y desinversión. Los diferentes tipos de habitantes, de los cuales se da cuenta desde la perspectiva weberiana, representan un tipo ideal, reflejo de una construcción mental 
que tiene el rasgo de ser utópica en sí, obtenida a partir de una exageración mental y perceptual de determinados elementos de la realidad analizada (De Donato, 2007). Las variables más significativas en la definición de los rasgos diferenciadores y convergentes, fueron: el barrio que escogen; los criterios tras la elección; el ingreso per cápita en una escala comparada que comprende a todos los entrevistados; su trayectoria residencial y socioprofesional; su nivel de ocupación; y las prácticas espaciales, respecto de las cuales se identifica si están ancladas y arraigadas al barrio elegido, o bien corresponden a sujetos multimóviles.

En este estudio no se pretende configurar a los tipos de habitantes definidos como clonables a otros espacios; más bien, responden a un primer ejercicio cualitativo y función heurística en tanto hipótesis que sostiene que a los espacios centrales arriban sujetos que van más allá de los gentries. No representan conceptos de clases, sino términos límites formados por síntesis (De Donato, 2007), que permiten comprender mejor los fenómenos de cambio socioespacial que afectan a las áreas centrales. Por ende, desde la geografía de la diferencia y desde las teorías sociológicas de la desigualdad, se buscó identificar sus diferencias culturales, las historias de vida, el sentido de sus prácticas espaciales y las formas de apropiación o reapropiación de los espacios. La propuesta de nuevos habitantes de este artículo es contestataria de aquellas reflexiones que categorizan los nuevos habitantes de áreas centrales en función a una variable, o en virtud a estereotipos según sexo, color y ocupación. Tal como sostiene Chaney (1996), se requieren explicaciones complejas en función de su identidad, afiliación territorial e incluso, las trayectorias de vida de los individuos y sus grupos familiares. Las características que aquí se les atribuyen no son creaciones ni adopciones artificiales, más bien recursos interpretativos y formas de conocimiento local de un espacio sometido a transformaciones múltiples. 


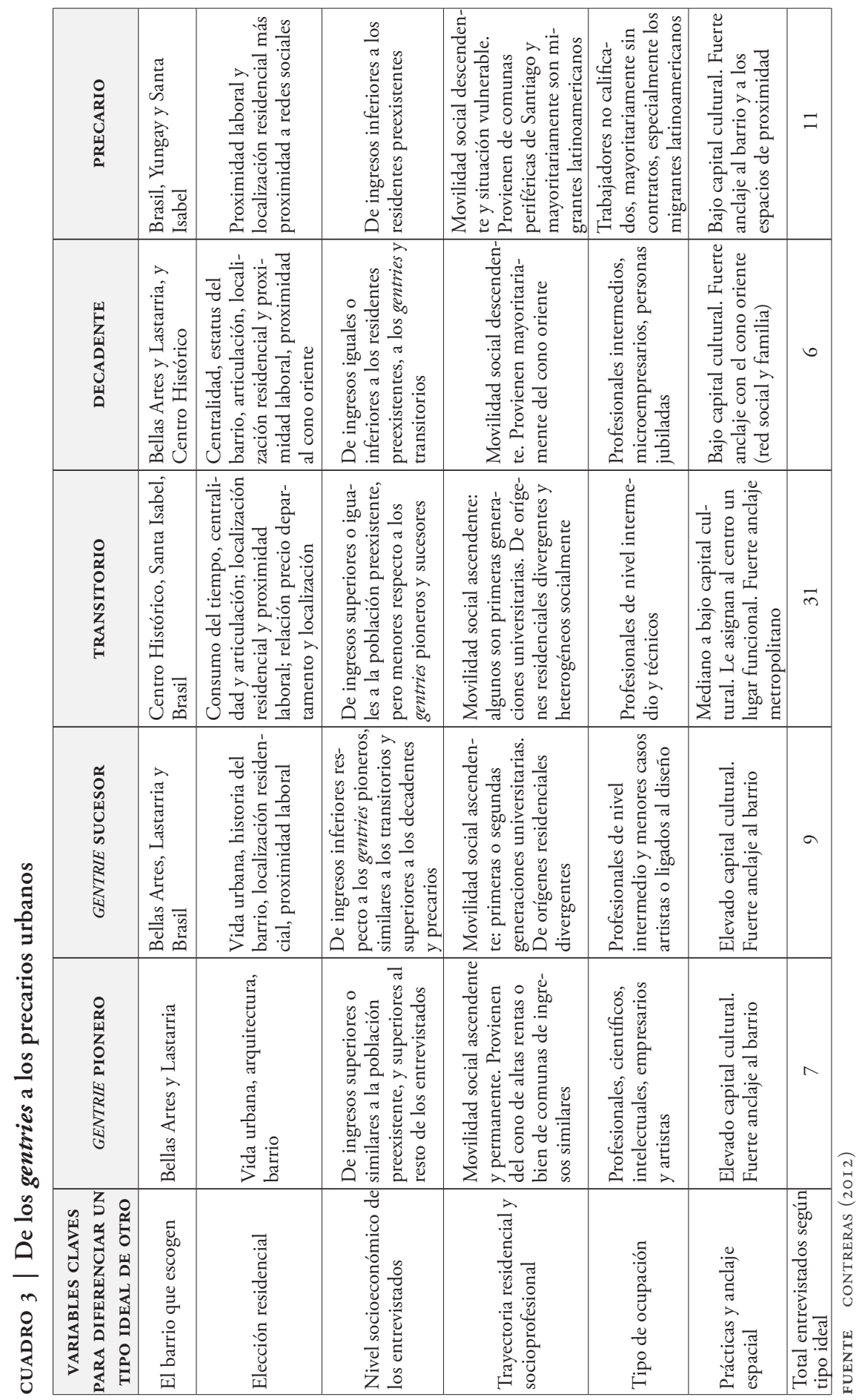


Seis fueron las variables claves que permitieron diferenciar a los habitantes entre sí. Al respecto, el nivel de ingresos no fue determinante al momento de establecer divergencias entre ellos. Algunos entrevistados tenían ingresos per cápita superiores a 800.000 pesos (US\$1.203), pero habitaban en condiciones de vulnerabilidad en residencias antiguas, deterioradas y en condición de hacinamiento. El ingreso se convirtió, por tanto, en la variable menos objetivable de las entrevistas. El nivel de educación, medido a través de la trayectoria de cada individuo, permitió delimitar y diferenciar a un habitante respecto de otro. En sus historias de vida se les consultó sobre las trayectorias residenciales y socioprofesionales de sus padres, a objeto de discutir qué los vuelve diferentes en cuanto a sus orígenes parentales. Los factores tras la elección del espacio e inmueble se configuraron como variables claves para establecer divergencias entre ellos y conformar los tipos ideales. Del cruce de estas variables surgieron los cinco tipos de habitantes ya señalados, que en forma descendente socioeconómicamente se repartieron de la siguiente forma: 7 gentries pioneros, 9 gentries sucesores, 31 transitorios, 6 decadentes y 11 personas categorizadas como precarios urbanos. Estos tipos de habitantes se proponen como categorías dinámicas y no cerradas. Los espacios habitados se presentan en la figura 2.

\section{FIgURA 2 Tipos de habitantes en la comuna de Santiago}

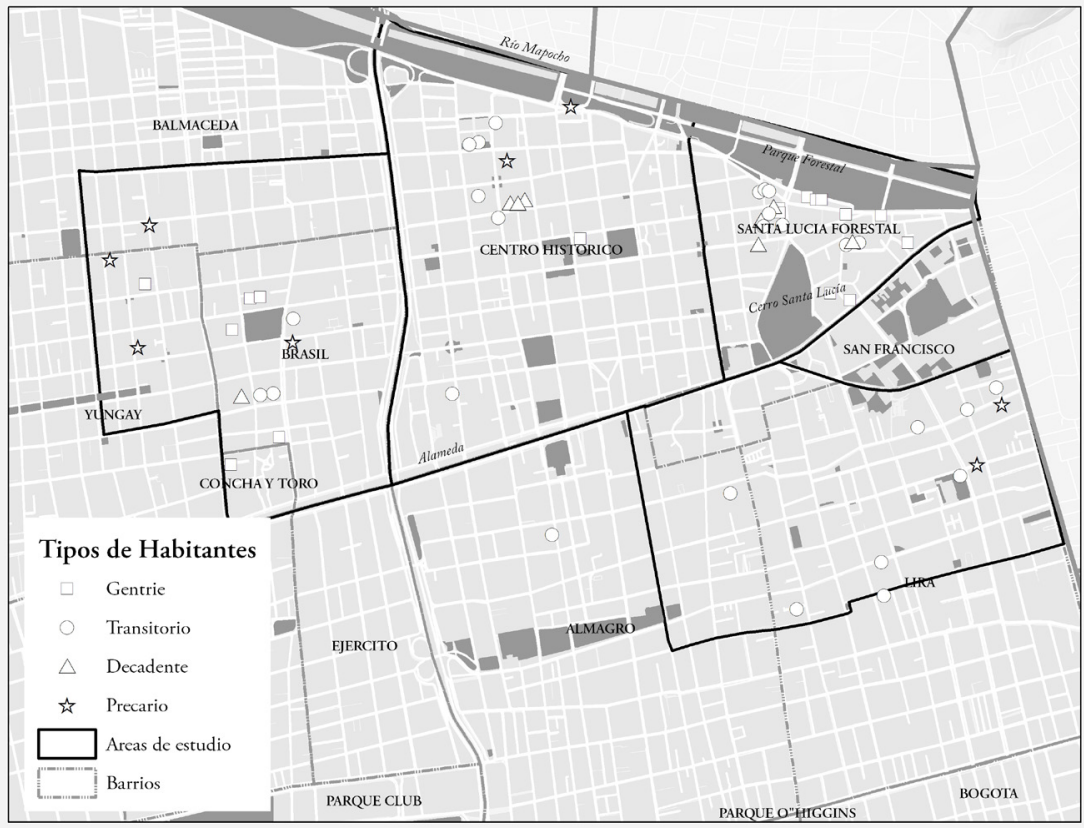

FUENTE CONTRERAS (2OI2) 
De manera específica, a continuación se explicitan las convergencias y divergencias entre los entrevistados analizados.

\section{Gentries pioneros y sucesores}

La designación de gentrie en el caso particular de la comuna de Santiago va más allá de la especificación de "clase social" designada por Glass (1964). De ahí que no se asume la definición original del término 'gentrificación', por cuanto diferentes áreas centrales de la comuna de Santiago acogen hoy a individuos que no necesariamente pertenecen a la élite suburbana, y también porque, en la definición original, los citadinos a los que se refiere pertenecen a un contexto político, económico, cultural y sociodemográfico difícil de comparar con la realidad latinoamericana, y en particular la chilena. En el caso estudiado, los gentries, tanto pioneros como sucesores, responden a las nuevas clases medias profesionales, para cuya identificación no existe consenso en la literatura (Butler, 2007; Ley, 1980; Smith, 1996). No obstante, lo que los hace diferente respecto a otras clases medias es que son buscadores de símbolos y signos de consumo y de cultura, y que en la mayoría de los casos están insertos en un proceso de movilidad social ascendente. El anclaje al barrio, la forma de practicar cotidianamente el territorio y sus sociabilidades los convierten, además, en sujetos distintos al habitante urbano tradicional.

En el estudio se asume, por ende, una visión más contemporánea de la gentrificación, en especial como un proceso de cambio socioespacial y residencial anclado en barrios centrales consolidados, y que resulta del arribo de mejores pagadores del suelo, que desplazan voluntaria o involuntariamente a hogares de menores ingresos. Algunas manzanas de los barrios Brasil y Yungay (figura 2) acogieron a gentries pioneros en antiguas casonas recicladas como departamentos loft, por acciones coercitivas de agentes inmobiliarios que ofertan viviendas para un nicho de mercado que privilegia la vida de barrio y la proximidad a grupos socioespaciales divergentes. Son estas manzanas las representativas de un patrón clásico de gentrificación; por tanto, en ellas se constata desplazamiento de familias de bajos ingresos que habitan en condición de arrendamiento, especialmente a inicios de la década de los años noventa.

En la actualidad, las manzanas del barrio Yungay se caracterizan por la coexistencia de grupos sociales diferentes, que incluyen grupos medios profesionales, grupos medios altos y bajos, estos últimos representados por inmigrantes latinoamericanos que acceden al mercado informal de viviendas deterioradas. La comuna de Santiago -más específicamente el triángulo de mayores ingresos correspondiente al barrio Bellas Artes y Lastarria- concentra a gentries diferentes a los descritos por Glass. En primer lugar, porque si bien representan a élites ligadas al arte, la cultura, también lo escogen empresarios y profesionales de ingresos medios altos y medios para quienes el lugar cumple un rol significativo como espacio arquitectónico, patrimonial, histórico y cultural. En segundo lugar, se enmarcan en la perspectiva culturalista de la gentrificación (Hamnett, 2001, 2003; Ley, 1980, 1981). Responden a grupos situados en un contexto de reducción del tamaño del hogar, de aumento del nivel de ingresos, incremento de los divorcios e, incluso, de mayor valoración de la cultura y el consumo. Tienen un papel preponderante en la recuperación de 
los barrios, siendo pioneros de la gentrificación y de la comprensión del patrimonio más allá de lo tangible.

El nivel de educación del jefe del hogar entre los gentries, es universitario; algunos incluso tienen doctorados y posdoctorados. En el caso de los barrios Bellas Artes y Lastarria, algunos entrevistados entregan la posta a iguales, es decir, responden a un proceso de invasión y sucesión de clases medias altas y medias con elevado capital cultural y educacional. Se trata, en ciertas situaciones, de habitantes de retorno, que residieron en el barrio en los años ochenta o noventa; en menos casos, son hijos o nietos de élites que vivieron allí entre los años treinta y sesenta. En tres de las cuatro zonas de estudio, los gentries están representados por profesionales científicos, intelectuales, empresarios, artistas y profesionales intermedios con una gran valoración por la arquitectura, el patrimonio y el sentido de habitar un barrio. Arribaron masivamente entre 1990 y 1995, accediendo a departamentos antiguos que rehabilitaron o a casonas antiguas deterioradas, que posteriormente reciclaron.

Como se ha visto, dentro del grupo de los gentries se ha definido una subcategoría, los gentries sucesores (cuadro 3 y figura 2), representada por 9 entrevistados, que asumen rasgos de los gentries pioneros, así como de los habitantes transitorios. De los gentries pioneros asimilan gustos, preferencias y prácticas espaciales. También escogen o buscan barrios patrimoniales e históricos, aunque comparten con los residentes transitorios la valoración del consumo de bienes y servicios. Se diferencian de estos últimos en que tienen ingresos superiores a ellos, pero menores que los de los gentries. Como los transitorios, los gentries sucesores en su mayoría representan primeras generaciones universitarias inscritas en un proceso de trayectoria profesional y económica ascendente, con aumento relativo del nivel de ingresos y mayor poder de endeudamiento, respecto a los hogares parentales; también comparten algunas características en cuanto a orígenes sociales, lugares recorridos y proyecciones residenciales. Y al igual que los gentries pioneros, los sucesores valorizan el barrio, tienen prácticas ancladas a este, y buscan el "entre sî" diferenciador, lo que los vuelve categorías comunes desde estas dimensiones subjetivas.

\section{Los transitorios urbanos o "aves de paso" en los barrios del centro}

Este grupo fue clasificado como transitorio urbano o "ave de paso" (Timms, 1976). En sus discursos, el área central representa, objetiva o subjetivamente, una etapa en su ciclo de vida. Objetivamente, porque algunos están comprando parcelas de agrado o viviendas en condominios cerrados en la periferia de Santiago a las cuales tienen previsto trasladarse; y subjetivamente, en tanto algunos casos desean habitar en las áreas suburbanas de la Región Metropolitana de Santiago. Los términos 'transitorio' o 'ave de paso' aluden a un ser pasajero o vivir temporalmente en un lugar. Las aves de paso caricaturizan las nuevas clases medias chilenas, en especial a profesionales y técnicos, en muchos casos primeras generaciones universitarias. Arribaron masivamente a las zonas de estudio a partir del año 2004, fecha en que la gestión de la Cordesan y del Municipio se consolidaron bajo la lógica del empresarialismo urbano, beneficiando así al mercado inmobiliario, que capturó el rent gap de espacios bien localizados. Menos casos llegaron entre los ańos 1995 y 1996, es decir, durante la fase intermedia del Plan de Repoblamiento y cuando el mercado 
inmobiliario consolidó su imagen de agente rentabilizador de diferentes lotes de la comuna.

Los orígenes residenciales de los transitorios urbanos son diversos. Algunos nacieron y habitaron en diferentes barrios del centro; otros, en cambio, nacieron o habitaron en una residencia de la periferia compacta de Santiago, o bien en otras ciudades del país. Se diferencian de los gentries en que sus elecciones residenciales están asociadas al valor del consumo en todas sus dimensiones, más que a condiciones históricas y simbólicas de los barrios donde habitan. Aprecian la accesibilidad y conectividad espacial, en relación con las posibilidades del territorio como sitio de ancla hacia diferentes espacios de la región metropolitana; y también social, por cuanto desde su residencia pueden acceder a sus redes sociales y familiares con facilidad. Sus prácticas espaciales cotidianas, sus trayectorias y anclajes residenciales, no han sido completamente explorados.

Este proceso de arribo de clases medias de diferentes orígenes residenciales no es exclusivo a la comuna de Santiago. Otros investigadores también lo reconocen para otras áreas centrales latinoamericanas, como Buenos Aires (Herzer et al., 2008), Bogotá (Bonvalet \& Dureau, 2002; Dureau, 2002) y México (Hiernaux, 1999).

Los 31 transitorios entrevistados tienen entre 24 y 55 años. Ellos o sus parejas son profesionales o técnicos de ocupaciones intermedias, en especial ingenieros, arquitectos, geógrafos, sociólogos, antropólogos, biólogos, profesores de enseñanza media o básica, microempresarios, tecnólogos ambientales, dentales, entre otros afines. Su nivel educativo es similar o más elevado que el de los decadentes urbanos y superior respecto al hogar parental. Son mayoritariamente personas con una opción de vida en solitario, o parejas que han optado por no tener hijos. Menos son los casos de parejas con hijos y de separadas con hijos. Constituyen una nueva figura familiar para quienes el ahorro y el acceso a una vivienda en propiedad es parte de un proceso mayor de movilidad social. Los proyectos de extensión del grupo familiar están asociados a una mejor condición económica. Algunos retrasan la maternidad o paternidad para dar cumplimiento a otros proyectos; en otros casos, la parentalidad no es parte de su proyecto familiar, independientemente del ciclo de vida en que se encuentren. Sus condiciones de vivienda son mejores que las de los precarios, pero similares a los decadentes urbanos, por cuanto son sujetos vulnerables en relación con la flexibilidad de sus trabajos y dependencia exclusiva de sus actividades laborales para su subsistencia económica, en una situación que no se ve resguardada por el posible apoyo de sus hogares parentales, como en el caso de los gentries pioneros. Acceden en un gran número a departamentos nuevos, con una oferta masiva en las áreas aquí estudiadas, a excepción de los barrios Bellas Artes y Lastarria, donde las viviendas usadas son las más ofertadas y demandadas. Finalmente, tienen como punto de anclaje el departamento y el centro, mientras sus recorridos, tiempos y espacios varían. Para ellos, el barrio es un nodo y un recurso que les asegura movilidad espacial y social.

\section{Decadentes urbanos}

La comuna de Santiago no solo acoge a habitantes de ingresos similares o superiores respecto a sus antiguos residentes; también se constituye en espacio donde arriban grupos sociales e individuos de ingresos inferiores a la población preexistente, o bien en una condición económica, social o familiar vulnerable. Se trata de un grupo 
aquí denominado "decadente urbano", es decir, habitantes de ingresos similares e incluso inferiores a los residentes anteriores, pero que enfrentan una condición de vulnerabilidad familiar, económica o social que influye en su elección residencial central. De los seis entrevistados clasificados como decantes, gran parte nació o vivió parte de su vida en comunas de altos ingresos de la ciudad de Santiago; entre ellas, Providencia, Nuñoa, Vitacura y Las Condes.

Para este grupo, el centro de Santiago actúa como ancla desde la cual rearticulan y definen sus prácticas espaciales en un estado de vulnerabilidad. Los barrios patrimoniales del centro histórico, en especial Bellas Artes, Lastarria, Centro Histórico, $y$ en menores casos Brasil, se convirtieron en objetos residenciales no solo para jóvenes y adultos profesionales, sino también para adultos y adultos mayores separados, viudos y jubilados con una condición económica desmejorada respecto a los gentries pioneros y sucesores y a los residentes transitorios). Desmejorada, ya sea por los costos económicos que involucra una ruptura matrimonial, la muerte del jefe de hogar o el quiebre de una fuente laboral. Un decadente está marcado por acontecimientos familiares (Bonvalet \& Dureau, 2002), como rupturas, separaciones, viudez, entre otros similares que son sinónimos de inestabilidad, inseguridad, vulnerabilidad económica o familiar.

Para los decadentes urbanos, vivir en el centro constituye un nodo a partir del cual se rearticulan las prácticas y se perpetúan sus redes sociales y familiares, especialmente con sus lugares de origen o los espacios habitados en diferentes comunas del cono oriente de altas rentas. Se encuentran sometidos a un riesgo económico, social o familiar, pero tienen la capacidad de enfrentarlo a partir del capital social que van construyendo. Comprenden clases medias y, en menores casos, medias altas, con trayectorias socioeconómicas descendentes respecto al estado anterior, sea por causas netamente económicas, o familiares y de su estado civil. Intentan mantener estilos de vidas y prácticas cotidianas similares a las que tenían en otras épocas. Aspiran, sueńan y desean regresar al lugar de origen, especialmente al cono oriente de altas rentas de la ciudad de Santiago y al modo de vida anteriormente practicado. Acceden mayoritariamente al parque habitacional antiguo, aunque existe un caso que vive en un departamento loft (cuadro 3). La tipología loft se configura como una residencia que devela signos y símbolos de estatus respecto de otras ofertas residenciales. En las otras zonas (Centro Histórico y Brasil-Yungay) los decadentes, habitan en departamentos nuevos en edificios en altura representativos de la verticalización pos-repoblamiento.

Los ingresos promedio per cápita de este grupo son bajos respecto a los gentries y transitorios, oscilando entre los 150.000 pesos (US\$255) en el caso de las mujeres jubiladas y los 900.000 pesos (us\$1.525). Desde el nivel de ingresos y la ocupación se advierte una aparente vulnerabilidad social de las personas de la tercera edad, en especial porque están expuestas a "circunstancias adversas para su inserción social y desarrollo personal” (Cepal, 2002), asociadas a lo avanzado de su edad. No obstante, y a diferencia de otros grupos, como los transitorios y precarios urbanos, esa vulnerabilidad social se reduce al mantener estas personas vínculos fuertes con sus redes sociales y familiares, que les aseguran la subsistencia o bien los apoyan en los diferentes consumos de bienes y servicios que requieren. 
Finalmente, los aquí denominados "decadente urbano" representan a los herederos de la cultura de la incertidumbre, de la inseguridad y de la vulnerabilidad, aunque esta condición no es exclusiva de ellos; es un rasgo a partir del cual diferentes autores caracterizan a las nuevas clases medias, a los transitorios y a los precarios urbanos. Agregar la condición de vulnerabilidad a los decadentes se explica esencialmente porque son el grupo que lo hace más explícito en sus discursos y en sus prácticas.

\section{Precarios urbanos}

Desde los años noventa y con mayor fuerza después del año 2000, diferentes barrios de la comuna de Santiago en procesos de transformación y renovación urbana no solo acogen a habitantes de ingresos similares o superiores a la población preexistente, sino que también fueron objeto de elección por parte de grupos sociales de bajos ingresos -nativos del país e inmigrantes latinoamericanos-, para quienes la centralidad cobra un nuevo sentido funcional, material y socioespacial. Los 11 precarios estudiados se localizan de manera dispersa en ciertas manzanas de los barrios objeto de estudios, especialmente en la zona Santa Isabel (1 chilena, 2 peruanos), seguida por los barrios Yungay, conglomerado de fuerte presencia migratoria más diversa en términos de origen respecto a otras zonas, como en los sectores Bogotá, en torno a la avenida Santa Isabel, y al sur de Avenida Matta. En relación con la llegada al país y al barrio, la mayoría lo hizo después del año 2000, siendo la comuna de Santiago el primer lugar de residencia en la ciudad de Santiago, dado los contactos realizados desde su lugar de origen.

Como "precario urbano" se denominó a personas de ingresos inferiores a los de la población preexistente, trabajadores en su mayoría no calificados que habitan en zonas tugurizadas próximas a las áreas de renovación urbana y verticalización, e incluso colindantes con ellas. Esta categoría, por una parte, incluye viejas clases medias residentes cuyas condiciones de vida se han precarizado y deteriorado a causa del envejecimiento de los sostenedores del hogar, y su consecuente salida del mercado laboral o desproletarización. Por otra, abarca a nuevos habitantes del centro que lo escogen por los atributos asociados a la localización y cuya inserción laboral inestable no les permite acceder a ingresos para financiar una vivienda con un estándar de habitabilidad adecuado. En esta categoría se considera tanto a nativos como a inmigrantes latinoamericanos. La diferencia entre ellos radica en que gran parte de los inmigrantes aquí entrevistados accede a viviendas a través del mercado informal; en cambio, los nativos heredaron viviendas, lo que -en términos relativos- los vuelve menos vulnerables que los inmigrantes.

Los precarios urbanos se localizan preferentemente en los barrios Brasil-Yungay, Centro Histórico y, de forma dispersa, en la zona Santa Isabel. El patrón de concentración de los inmigrantes, especialmente en la zona poniente de la comuna (barrios Brasil, Yungay, Centro Histórico) dada la mayor oferta de viviendas deterioradas, en condición de arrendamiento y hacinamiento, aunque a precios de un rango semejante a los de otros lugares de la ciudad (Torres \& Hidalgo 2007; Granados 2009). Representan la nueva geografía social de áreas centrales de la ciudad, como la comuna de Santiago. 
La presencia de los precarios tampoco es un fenómeno nuevo. Lo diferente es la masividad del proceso migratorio para el caso de la comuna de Santiago, su poder de transformación en la estructura urbana y la búsqueda de espacios de integración y adaptación dentro del centro (Granados, 2009). En el caso de muchos de los inmigrantes, su situación de inseguridad laboral está asociada a su calidad de personas en proceso de legalizar la presencia en Chile. Un menor número de precarios tiene trabajos formales, pero el rasgo más característico de este grupo es que acceden a trabajos informales o independientes como fuente de ingresos. Los nativos están resguardados por la pertenencia - legal o informal- de una vivienda heredada o entregada en comodato. Otros, en cambio, dependen de trabajados complementarios que realizan durante el día y también el fin de semana, siendo bilaborales por necesidad y no por opción, como algunos gentries. Para los bilaborales, la flexibilidad del trabajo se convierte en una estrategia que asegura ingresos superiores y mejora el acceso a la oferta de alojamientos dentro de los barrios del centro de Santiago.

La conformación de los grupos familiares se estructura en la mayoría de los casos en torno a la figura de padre, madre e hijo, aunque en el caso de los chilenos se trata de estructuras familiares diferenciadas: algunas mujeres están separadas y otras son viudas. El estatuto de ocupación de la vivienda de los precarios refleja un acceso a la vivienda informal y precaria en pleno centro de la ciudad. Las viviendas de los inmigrantes se caracterizan por condiciones de habitabilidad exigua y precaria, reducidas algunas incluso a sótanos, subterráneos y a espacios sin ventilación. Se localizan en las manzanas menos privilegiadas del empresarialismo urbano, pero funcionales al neoliberalismo. Se trata de habitantes que acceden al mercado de la vivienda usada, con el alquiler como la modalidad masiva de ocupación, asociada al negocio inmobiliario de los nuevos conventillos donde opera un mercado de piezas y habitaciones subarrendadas por los inmigrantes (Contreras, 2012; Torres \& Hidalgo, 2007).

El arribo de inmigrantes a algunos barrios históricos de la comuna de Santiago no es un fenómeno nuevo; más bien, es parte del ciclo de vida urbano de los espacios centrales (Castillo \& Hidalgo, 2007; Hidalgo, 2002). Quizás lo nuevo radica en las condiciones infrahumanas en las que habitan, y en el estigma que pesa sobre ellos, al no ser chilenos. Desde una dimensión espacial e histórica, lo interesante de los precarios urbanos inmigrantes es que coexisten con viejas clases medias empobrecidas o menos vulnerables, en tanto heredaron una casa que les asegura un ancla bien conectada al sistema metropolitano. Asimismo, coexisten inmigrantes latinoamericanos en los mismos espacios donde arribaron migrantes internos en el período de industrialización chilena de los años treinta.

\section{De los gentries a los precarios urbanos.}

\section{Representativos de trayectorias residenciales diversas}

Los habitantes descritos anteriormente refuerzan la tesis sobre el centro de Santiago como un mosaico socioespacial dinámico, en transformación tanto residencial como cultural, comercial y social. Los tipos identificados en el artículo son categorías dinámicas y quienes las integran pueden transitar desde un tipo a otro, dependiendo de sus trayectorias socioprofesionales y teniendo presentes sus gustos, preferencias y restricciones, especialmente en cuanto al acceso a la vivienda formal central. Tal 
tipología constituye una primera aproximación para comprender qué hace diferentes a los habitantes que llegaron al centro de Santiago desde los ańos noventa en comparación con los precedentes, ya sea en el marco del Plan de Repoblamiento activado por la Municipalidad de Santiago a través de la Cordesan, de acciones del mercado inmobiliario privado, o bien a partir de iniciativas particulares orientadas a recuperar antiguos inmuebles deteriorados en zonas patrimoniales e históricas.

Las trayectorias residenciales de los grupos estudiados reflejan al menos tres patrones sociogeográficos de movilidad, espacializados en la figura 3: (i) una fuerte movilidad residencial desde áreas periféricas hacia el centro; (ii) una fuerte movilidad por contigüidad sociogeográfica, desde el sector oriente de altas rentas hacia los barrios centrales y, en menor medida, hacia los barrios Brasil, Santa Isabel y Centro Histórico; y (iii) una intensa movilidad intrabarrios, siendo los espacios más recorridos el barrio Brasil, la zona Santa Isabel y los barrios Bellas Artes y Lastarria. El conjunto de estos movimientos internos refuerza la tesis de un centro que asume un rol residencial más allá de la multiplicidad de funciones que lo caracterizan.

Para cada uno de los grupos estudiados, los barrios de la comuna de Santiago se convirtieron en el espacio de proximidad y lugar de la ubicuidad, a partir del cual se establecen vínculos geográficos y sociales con el resto del sistema metropolitano. La proximidad resulta una dimensión subjetiva que varía de un tipo de habitante a otro. Para los gentries, implica la cercanía a sus redes sociales, familiares y a las amenidades culturales, y explica en parte sus elecciones residenciales. El barrio Bellas Artes es una proyección elitizada de la vida social del sector oriente del que provienen. Contrariamente, para los transitorios la proximidad está definida por la cercanía al trabajo y la conectividad hacia diferentes puntos de la ciudad donde se localizan sus redes sociales y familiares. Para los decadentes, la proximidad resulta un recurso de continuidad con el cono de altas rentas y la cercanía a sus redes sociales y familiares y los espacios frecuentados. Los precarios valoran la proximidad al trabajo y a las redes sociales. Así, en cada una de las elecciones de estos grupos aparece la proximidad como capital de movilidad.

A excepción de los gentries pioneros, la mayor parte de los entrevistados para este estudio está marcada por una condición de vulnerabilidad, sea familiar, económica o social. Familiar, en el sentido de que para muchos de ellos el centro se convirtió en una elección residencial luego de una ruptura matrimonial, separación, abandono o término de un ciclo de vida, asociado a una jubilación y a la entrada a la tercera edad. Vulnerabilidad económica, para las personas que trabajan de manera informal, independiente, o aquellos que son bilaborales, estando sus ingresos supeditados a la combinación de trabajos informales. Y social, especialmente en el caso de los inmigrantes, porque sus lugares de residencia les hacen experimentan situaciones de segregación, discriminación y xenofobia, las que se producen incluso entre migrantes latinoamericanos de diferentes nacionalidades. Esto último pone en evidencia la transformación de la geografía social del espacio urbano central, que exige hacer legible la coexistencia social y espacial de todos los grupos sociales que hoy están disputando la residencia o el comercio dentro de los barrios centrales que se renuevan, y que son sujetos de un proceso de gentrificación de menor escala, 
muchas veces más silencioso que las edificaciones en altura. Muchos de tales grupos habitan, así, en espacios latentes de procesos de gentrificación.

FIGURA 3 | Trayectorias residenciales de los gentries, transitorios, decadentes y precarios
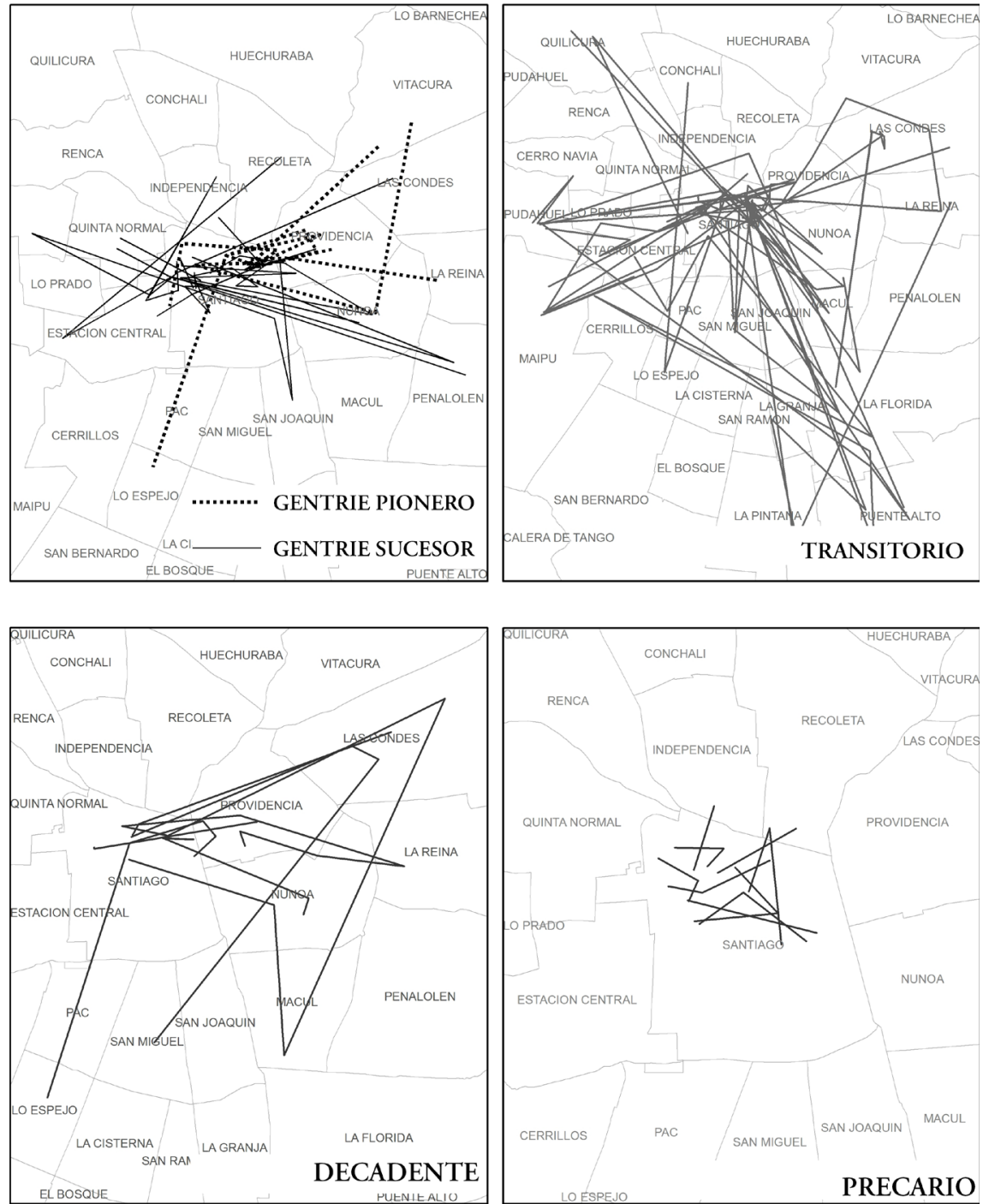

FUENTE ELABORACIÓN PROPIA, A PARTIR DE ENTREVISTAS EN PROFUNDIDAD 


\section{Conclusiones}

El estudio de los tipos de habitantes aquí presentados (gentries pioneros y sucesores, residentes transitorios o "aves de paso", decadentes y precarios urbanos) revela, en primer lugar, la transformación de la geografía social del espacio urbano central y exige identificar las diferentes formas de división del espacio, asumiendo las exageraciones mentales utópicas que acechan al tratar de encasillarlos a priori en cinco categorías. El centro de Santiago es un espejo de las desigualdades socioterritoriales a escala ciudad. Los mejores espacios en términos de localización y concentración de amenidades urbanas y ambientales en la comuna de Santiago se encuentran en su borde nororiente, en contigüidad con el sector oriente de altos ingresos; en cambio, los espacios relegados al deterioro, informalidad y tugurización tienden a localizarse hacia el borde sur y poniente de la comuna, y se encuentran demandados por una oferta inmobiliaria especuladora que rentabilizó en diferentes predios de la comuna de Santiago.

En segundo lugar, la existencia de diferentes grupos sociorresidenciales en la comuna evidencia la realidad de una "sociedad extraordinariamente compartimentada" (Fol, 2009, p. 43), donde las fronteras y relaciones de sociabilidad se establecen en el seno de cada grupo social, lo que pone en tensión la coexistencia social. Ante ello, es preferible una mezcla socioespacial en barrios centrales frente a la relegación de los espacios periféricos, donde generalmente el capital de movilidad de los hogares de más bajos ingresos se ve reducido.

Es probable que la movilidad residencial de los precarios -es decir, sus posibilidades de cambio de residencia- esté limitada por su condición de vulnerabilidad y se restrinja a ofertas residenciales periféricas de muy baja calidad. Esto último obliga al Estado, y a la actual política habitacional, a destinar recursos y subsidios que aseguren un acceso residencial igualitario, promoviendo así el mercado del alquiler en espacios centrales y pericentrales, donde existen inmuebles subutilizados y posibles de ser reconvertidos, en los cuales proyectar vivienda, comercio, servicios, entre otros usos.

Los tipos ideales aquí presentados no intentan constituirse en tipos exportables. Más bien, constituyen un primer ejercicio mental y subjetivo orientado a visibilizar las prácticas espaciales de los grupos que los integran, sus necesidades y proyecciones residenciales. Cada uno y todos ellos son dinámicos. Un gentrie sucesor puede ser decadente en la medida en que atraviese una condición de vulnerabilidad que lo sitúe en una trayectoria social, económica o familiar descendente. Un transitorio puede constituirse en gentrie en la medida en que asigne mayor valor al capital cultural y a los barrios escogidos, aunque no podría ser un gentrie pionero, pues la pionerización está marcada por el tiempo y el espacio de arribo al área central. Los decadentes pueden ser transitorios en la medida en que sus trayectorias socioeconómicas tiendan al ascenso. Lo anterior implica que la descripción de los tipos de habitantes exige comprender que están circunscritos a tiempos y espacios diferenciados. Algunos llegaron al centro de Santiago cuando sus barrios experimentaban una condición de obsolescencia urbana, o bien enfrentaban un proceso de transición que abría las puertas a la inversión, incitando así a un proceso de recuperación y gentrificación. Otros, en cambio, arribaron a los barrios durante las fases de renovación 
y gentrificación en sus primeras etapas. Los espacios y tiempos que habitan estos grupos reflejan las diferentes dinámicas por las que atraviesa el centro de Santiago.

El ejercicio de establecer tipos de habitantes está limitado por el aumento de los grupos medios y por la nebulosa "nueva clase media". Al respecto, la falta de consenso sobre qué significa ser y pertenecer a la clase media dificultó el análisis y la posterior clasificación de los entrevistados. Pese a la falta de claridad y dada la fuerte diversidad de los entrevistados, existieron convergencias en función de sus prácticas espaciales, las trayectorias sociales, residenciales y/o familiares. El análisis de los entrevistados permitió su identificación como actores del cambio socioespacial de diferentes sectores de la comuna de Santiago, para luego establecer una clasificación diferenciadora en el marco de ese grupo general.

El proceso descrito, que va desde la gentrificación a la precarización de zonas centrales, revela la coexistencia de habitantes con distintas trayectorias residenciales y socioprofesionales. El ejercicio político debiese focalizarse en cómo asegurar una oferta residencial en alquiler para los precarios urbanos, en tanto sujetos vulnerables. La mezcla socioespacial puede convertirse en un medio, discurso y recurso que, de ser mediatizados y mercantilizados, desatan procesos exclusionarios de gentrificación que deben ser advertidos por las autoridades locales y centrales. Es un desafío generar una política habitacional que evite el desplazamiento, esencialmente en espacios de gran acceso y oportunidad territorial.

\section{Referencias bibliográficas}

Abramo, P. (2012). La ciudad com-fusa: mercado y producción de la estructura urbana en las grandes metrópolis latinoamericanas. EURE, 38(114), 35-69. http://dx.doi. org/10.4067/S0250-71612012000200002

Appleyard, D. (1979). The conservation of European cities. Cambridge, MA: The MIT Press.

Authier, J. Y. (Dir.). (2001). Du domicile à la ville. Vivre en quartier ancien. Coll. Villes. París: Anthropos.

Authier, J. Y. \& Bidou-Zachariasen, C. (2008). La question de la gentrification urbaine. Espaces et sociétés, 1-2(132-133), 13-21. doi 10.3917/esp.132.0013

Barton, J. (2008). El poder de la gobernanza: el eslabón "perdido" de la sustentatibilidad urbana. En G. Yáñez Warner, A. Orellana, O. Figueroa \& F. Arenas (Eds.). Ciudad, poder y gobernanza (pp. 413-430). Santiago de Chile: Instituto de Estudios Urbanos, U. Católica de Chile, Serie EURE Libros - Instituto de Geografía, U. Católica de Chile, Serie GEOlibros, 9 - Colección Rideal.

Baudin, G. (2000). La mixité sociale: Une utopie urbaine et urbanistique. Revue du Crehu, (10), 13-23. https://halshs.archives-ouvertes.fr/halshs-00101442/document

Bonvalet, C. \& Dureau, F. (2002). Los modos de habitar: unas decisiones condicionadas. En F. Dureau, C. Bonvalet, E, Dupont, J. Levy \& T. Lulle (Eds.), Metrópolos en movimiento: Una comparación internacional (pp. 69-87). Bogotá, Colombia: IRD Éditions y Económica. 
Butler, T. (2007). For gentrification? Environment and Planning A, 39(1), 162-181. doi: $10.1068 / a 38472$

Carrión, F. (Ed.) (2001). Centros históricos de América Latina y el Caribe. Quito, Ecuador: Unesco - Banco Interamericano de Desarrollo - Ministerio de Cultura y Comunicación de Francia - Flacso-Ecuador.

Carrión, F. \& Hanley, L. (Eds.) (2005). Regeneración y revitalización urbana en las Américas: hacia un Estado estable. Quito, Ecuador: Flacso-Ecuador - Woodrow Wilson International Center for Scholars (wwics) - Agencia de los Estados Unidos para el Desarrollo Internacional (Usaid).

Chaney, D. (1996). Estilos de vida. Madrid: Talasa.

Contreras, Y. (2011). La recuperación urbana y residencial del centro de Santiago: Nuevos habitantes, cambios socioespaciales significativos. EURE, 37(112), 89-113. http://doi. org/10.4067/S0718-65682015000300004

Contreras, Y. (2012). Cambios socio-espaciales en el centro de Santiago de Chile: Formas de anclarse $y$ prácticas urbanas de los nuevos habitantes. Tesis presentada para la obtención del grado de Doctor en Arquitectura y Estudios Urbanos, Pontificia Universidad Católica de Chile, Santiago, y Universidad de Poitiers, Francia. https://tel.archives-ouvertes.fr/tel00684955/document

Contreras, Y., Ala-Louko, V. \& Labbé, G. (2015). Acceso exclusionario y racista a la vivienda formal e informal en las áreas centrales de Santiago e Iquique. Polis, 14(42), 53-78. http://doi.org/10.4067/S0718-65682015000300004

De Donato, X. (2007). El carácter de los tipos ideales weberianos y su relación con las ciencias naturales. Diánoia, 52(59), 151-177. http://www.scielo.org.mx/scielo.php?script=sci_ arttext\&pid $=$ S0185-24502007000200007

De Mattos, C. (2011). Metropolización y suburbanización. EURE, 27(80), 5-8. http://doi. org/10.4067/S0250-71612001008000001

Dureau, F. (2002). Bogotá: una doble dinámica de expansión espacial y de densificación de espacios ya urbanizados. En F. Dureau, C. Bonvalet, E. Dupont, J. Levy \& T. Lulle (Eds.), Metrópolos en movimiento: Una comparación internacional (pp. 28-46). Bogotá, Colombia: IRD Éditions y Económica.

Fol, S. (2009). La mobilité des pauvres: pratiques d'habitants et politiques publiques. Coll. Mappemonde. París: Belin.

Glass, R. (1964). London: Aspects of change. Centre for Urban Studies, Report 3. Londres: MacGibbon \& Kee.

Granados, S. (2009). Prácticas cotidianas de los inmigrantes latinoamericanos: espacios de integración y diferenciación al interior de la ciudad de Santiago. Tesis presentada al Instituto de Estudios Urbanos y Territoriales de la Pontificia Universidad Católica de Chile como uno de los requisitos para optar al Grado Académico de Magíster en Desarrollo Urbano. Santiago, Chile.

Hamnett, C. (1991). The blind men and the elephant: The explanation of gentrification. Transactions of the Institute of British Geographers [New Series], 16(2), 173-189. doi: $10.2307 / 622612$

Hamnett, C. (2003). Gentrification and the middle-class remaking of inner London, 19612001. Urban Studies, 40(12), 2401-2426. http://is.muni.cz/el/1431/jaro2006/Z4044/ um/1277696/GMreader4_1_Hamnett.pdf 
Harvey, D. (2003). Espacios de esperanza. Madrid: Akal.

Harvey, D. (2007). De la gestión al empresarialismo: la transformación de la gobernanza urbana en el capitalismo tardío. En D. Harvey, Espacios del capital. Hacia una geografía crítica (pp. 366-390). Madrid: Akal.

Herzer, H. (Org.) et al (2008). Con el corazón mirando al sur. Transformaciones en el sur de la ciudad de Buenos Aires. Buenos Aires: Espacio.

Hidalgo, R., Salazar, A. \& Álvarez, L. (2003). Los condominios y urbanizaciones cerradas como nuevo modelo de construcción del espacio residencial en Santiago de Chile (19922000) [versión electrónica]. Revista Electrónica de Geografía y Ciencias Sociales, Scripta Nova, 7(146-123). http://www.ub.edu/geocrit/sn/sn-146(123).htm

Hiernaux, D. (1999). Los frutos amargos de la globalización: expansión y reestructuración metropolitana de la ciudad de México. EURE, 25(76), 57-78. http:// doi.org/10.4067/ S0250-71611999007600003

Jaramillo, S. (2008). Reflexiones sobre la "informalidad" fundiaria como peculiaridad de los mercados del suelo en las ciudades de América Latina. Territorios, 18-19, 11-53. http:// revistas.urosario.edu.co/index.php/territorios/article/view/826

Lees, L., Slater, T. \& Wily, E. (2008). Gentrification. Londres: Routledge.

Ley, D. (1980). Liberal ideology and the postindustrial city. Annals of The Association of American Geographers, 70(2), 238-258. doi: 10.1111/j.1467-8306.1980.tb01310.x

Ley, D. (1986). Alternative explanations for inner-city gentrification: A Canadian assessment. Annals of The Association of American Geographers, 76(4), 521-535. doi: 10.1111/ j.1467-8306.1986.tb00134.x

Lévy, J. P., (2001). Parcours d'habitants. En J.-Y. Authier (Dir.), Du domicile à la ville. Vivre en quartier ancien (pp. 21-50). París: Anthropos.

López, E., Arriagada, C., Gasic, C. \& Meza, D. (2015). Efectos de la renovación urbana sobre la calidad de vida y perspectivas de relocalización residencial de habitantes centrales y pericentrales del Área Metropolitana de Santiago. EURE, 41(124), 45-67. http:// doi. org/10.4067/S0250-71612015000400003

Lloyd, R. (2002). Neo-Bohemia: Art and neighborhood redevelopment in Chicago. Journal of Urban Affairs, 24(5), 517-532. doi: 10.1111/1467-9906.00141

Ministerio de Vivienda y Urbanismo (Minvu). (2016). Informe Estadístico de Edificación. Datos del Observatorio Habitacional Minvu. http://www.observatoriohabitacional.cl/ opensite_20080122171157.aspx

Reich, R. (1993). El trabajo de las naciones. Hacia el capitalismo del siglo XXI. Traducido por Javier Vergara. Buenos Aires: Vergara.

Rasse, A. (2015). Juntos pero no revueltos. Procesos de integración social en fronteras residenciales entre hogares de distinto nivel socioeconómico. EURE, 41(122), 125143. http:// doi.org/10.4067/S0250-71612015000100006

Scheiner J. \& Kasper, B. (2002). Lifestyles, choice of housing location and daily mobility. The lifestyle approach in the context of spatial mobility and planning. Trabajo presentado en el 42nd Congress of the European Regional Science Association (ERSA), 27-31 agosto, Dortmund, University of Dortmund - Department of Transport Planning. Publicado en 2003 en International Social Science Journal, 55(176), 319332. doi: 10.1111/j.1468-2451.2003.05502011.x. 
Smith, N. (1979). Toward a theory of gentrification: A back to the city movement by capital, not people, Journal of the American Planning Association, 45(4), 538-548. http:// doi. org/10.1080/01944367908977002

Smith, N. (1982). Gentrification and uneven development. Economic Geography, 58(2), 139155. doi: $10.2307 / 143793$

Smith, N. (1996). The new urban frontier: Gentrification and the revanchist city. Londres y Nueva York: Routledge. http://bit.ly/1MYj5eo

Smolka, M. \& Biderman, C. (2011). Vivienda informal: una perspectiva de economista sobre el planeamiento urbano. Documento de Trabajo. Cambridge, MA: Lincoln Institute of Land Policy. http://bit.ly/2i0W3IP

Timms, D. (1976). El mosaico urbano. Hacia una teoría de la diferenciación residencial. Madrid: Instituto de Estudios de Administración Local (IEAL).

Torres, A. \& Hidalgo, R. (2007). Los peruanos en Santiago de Chile: transformaciones urbanas y percepción de los inmigrantes. Polis, 8(22), 307-326. http:// doi.org/10.4067/ S0718-65682009000100018

Valenzuela, M. (2000). Programa de Repoblamiento: Comuna de Santiago de Chile 1990-1998. Un programa de gestión local reestructurado en nuevas formas de asociación entre el sector público y privado. Santiago, Chile: Municipalidad de Santiago, Chile. Texto no publicado. 